\title{
Planktonic Ctenophora of the Madeira Archipelago (Northeastern Atlantic)
}

\author{
SONIA KM GUEROUN ${ }^{1,2^{*}}$, SUSANNE SCHÄFER ${ }^{1,3}$, FRANCESCA GIZZI ${ }^{1}$, SOLEDAD ÁLVAREZ1 ${ }^{1}$ JOÃO \\ GAMA MONTEIRO ${ }^{1}$, CARLOS ANDRADE ${ }^{2,4} \&$ JOÃO CANNING-CLODE ${ }^{1,5}$ \\ ${ }^{1}$ MARE - Marine and Environmental Sciences Centre, Agência Regional para o Desenvolvimento da Investigação Tecnologia e \\ Inovação (ARDITI), Madeira, Portugal. \\ ${ }^{2}$ Maricultura Centre of Calheta, Calheta, Madeira, Portugal. \\ ${ }^{3}$ GEOMAR Helmholtz Centre for Ocean Research Kiel, Germany. \\ ${ }^{4}$ Interdisciplinary Centre of Marine and Environmental Research (CIIMAR/CIMAR), University of Porto, Portugal. \\ ${ }^{5}$ Smithsonian Environmental Research Center, Edgewater, USA. \\ Corresponding author: Sonia KM Gueroun: \$sgueroun@mare-centre.pt; @ https://orcid.org/0000-0002-6650-0855 \\ Joao Gama Monteiro: "jmonteiro@mare-centre.pt, @ ittps://orcid.org/0000-0002-3401-6495 \\ João Canning Clode: झ jcanning-clode@mare-centre.pt, @ https://orcid.org/0000-0003-2143-6535 \\ Francesca Gizzi: !" francesca.gizzi@mare-centre.pt, @ https://orcid.org/0000-0001-9447-8694 \\ Soledad Álvarez Suárez: "soledadalvarezsuarez@mare-centre.pt, 내ttps://orcid.org/0000-0001-6821-0301 \\ Susanne Schäfer: \$sschaefer@mare-centre.pt, @ ittps://orcid.org/0000-0002-0344-0541 \\ Carlos Andrade: " carlos.a.andrade@madeira.gov.pt, @ https://orcid.org/0000-0002-8166-0013
}

\begin{abstract}
Ctenophores are fragile gelatinous organisms whose diversity and distribution are relatively unknown. For the first time, the occurrence of four planktonic species, namely Ocyropsis crystallina, Eurhamphaea vexilligera, Cestum veneris, and Beroe sp., was reported from Madeira Archipelago waters (NE subtropical Atlantic). This report represents the northernmost records in the Eastern Atlantic Ocean for O. crystallina and E. vexilligera.
\end{abstract}

Key words: Beroida, Cestida, Lobata, subtropical Atlantic

\section{Introduction}

Madeira Archipelago is one of two Portuguese island systems, including five major islands, Madeira, Porto Santo, and the three Desertas islands (Ilhéu Chão, Deserta Grande and Bugio). About $300 \mathrm{~km}$ southward, the small islands of Selvagem Grande and Selvagem Pequena are also part of the archipelago. The archipelago is located at the North Atlantic Subtropical Gyre's eastern boundary, with dominant north-eastern trade winds and typical oligotrophic conditions (Longhurst et al. 1995). The island system is mainly influenced by the Azores Current, which joins the Canary Current north and around Madeira Island (Sala et al. 2013). Madeira archipelago is one of the four Macaronesian island systems in the Eastern Atlantic (north to south: Azores, Madeira, Canary Islands, and Cape Verde) (Freitas et al. 2019). Despite its oceanic nature, marine biodiversity research in Madeira has been mainly focused on benthic invertebrates (e.g., Wirtz 2007; Alves et al. 2019; Cacabelos et al. 2019; Ramalhosa et al. 2021), fish (Ribeiro et al. 2005; Wirtz et al. 2008; Biscoito et al. 2018), and plankton diversity mainly restricted to phytoplankton (Kaufmann et al. 2015; Narciso et al. 2019). However, Ctenophora — a taxon included among macro gelatinous zooplankton-remains greatly unexplored in Madeira waters.

Despite their apparent biological "simplicity" and high water content, ctenophores are ecologically important in the marine environment. They are exclusively carnivorous (Haddock 2007) but also provide prey (Diaz Briz et al. 2017) and habitat for various organisms (Ohtsuka et al. 2009). In the last decades, ctenophores have attracted rising attention due to their fast growth leading to bloom events (Sullivan et al. 2001; Purcell 2005) but also due to the consequences of a particular species invasion (Mnemiopsis leidyi A. Agassiz, 1865) in several ecosystems (Knowler 2005; Boersma et al. 2007; Dinasquet et al. 2012). Despite ctenophores being distributed in all global ocean basins, they are still poorly studied compared to other gelatinous zooplankton taxa. To date, nearly 250 species have been 
described on a global scale (Giribet \& Edgecombe 2020). This gap in knowledge is related to these organisms' fragility, usually destroyed by classical plankton net sampling and the challenge of its preservation (Thibault-botha \& Bowen 2004; Engell-Sørensen et al. 2009). However, the technological evolution of research equipment, the simultaneous increase of SCUBA diving activities and advances in underwater photography increased ctenophore diversity and distribution records worldwide (Deidun 2011; Gibbon et al. 2021; Hidaka et al. 2021). Despite these developments, their diversity is still underestimated due to uneven sampling efforts, both geographically and between shallow and deep-sea habitats

In the Atlantic Ocean, ctenophore diversity has been mainly studied along the western coasts: 20 species have been reported in southern regions and around 19 from north American waters (Mayer 1912; Oliveira \& Migotto 2006; Migotto \& Marques 2007; Oliveira et al. 2016; Dutto et al. 2017). In the Eastern Atlantic, studies have been primarily concentrated in South Africa, with nine species and six morphospecies (Gibbons et al. 2021) and approximately nine species in the European North Atlantic (Greve 1975; Hansson 2006; Licandro et al. 2015). Currently, 16 planktonic ctenophore species have been recorded in Macaronesia: 15 in the Canary Islands, six in Cape Verde, and three in the Azores (Chun 1898; Gueroun et al. 2021). To date, Madeira's ctenophore records were restricted to a single benthic species, Vallicula multiformis Rankin, 1965 (Wirtz 1998).

Given the ecological importance of gelatinous zooplankton, updated information on local diversity is essential. This work represents the first record of planktonic ctenophores in the archipelago of Madeira.

\section{Material and Methods}

During 2020 and 2021 surveys and scientific dives in Madeira and Porto Santo islands, different species of ctenophores were opportunistically observed and recorded in the field (GoPro Hero 7, Paralenz Dive Camera Plus), and when possible, individually collected using plastic bags and glass jars (Fig. 1, Table 1). Collected specimens were kept in containers filled with seawater for transport to the laboratory. Ctenophores were then carefully placed in a petri dish with seawater, and images were taken using an Olympus ${ }^{\circledR}$ TG-6 camera (macro setting) on the same day.

TABLE 1. Geolocalization and depth of the ctenophores observed and sampled (examined material) in Porto Santo and Madeira islands (Madeira archipelago)

\begin{tabular}{|c|c|c|c|c|c|}
\hline Species & Island & Date & Coordinates & Depth (m) & Note \\
\hline \multirow{11}{*}{$\begin{array}{l}\text { Eurhamphaea } \\
\text { vexilligera }\end{array}$} & \multirow[t]{11}{*}{ Porto Santo } & $13-$ Oct-20 & $32^{\circ} 59^{\prime} 50.64^{\prime \prime} \mathrm{N} 16^{\circ} 23^{\prime} 01^{\prime \prime} \mathrm{W}$ & $0-6$ & observation \\
\hline & & & $33^{\circ} 00^{\prime} 13.21^{\prime \prime} \mathrm{N} 16^{\circ} 23^{\prime} 34^{\prime \prime} \mathrm{W}$ & $0-6$ & observation \\
\hline & & 14-Oct-20 & $33^{\circ} 00^{\prime} 18.72^{\prime \prime} \mathrm{N} 16^{\circ} 22^{\prime} 13^{\prime \prime} \mathrm{W}$ & $0-6$ & $\begin{array}{r}\text { Specimen studied } \\
\text { (halotype 1) }\end{array}$ \\
\hline & & & $33^{\circ} 00^{\prime} 19.08^{\prime \prime} \mathrm{N} 16^{\circ} 22^{\prime} 13^{\prime \prime} \mathrm{W}$ & $0-6$ & $\begin{array}{r}\text { Specimen studied } \\
\text { (halotype 2) }\end{array}$ \\
\hline & & & $33^{\circ} 03^{\prime} 45.00^{\prime \prime} \mathrm{N} 16^{\circ} 18^{\prime} 59^{\prime \prime} \mathrm{W}$ & $0-1$ & $\begin{array}{r}\text { Specimen studied } \\
\text { (halotype 3) }\end{array}$ \\
\hline & & $16-$-Oct-20 & $33^{\circ} 03^{\prime} 44.28^{\prime \prime} \mathrm{N} 16^{\circ} 18^{\prime} 59^{\prime \prime} \mathrm{W}$ & $0-1$ & observation \\
\hline & & & $33^{\circ} 03^{\prime} 03.60^{\prime \prime} \mathrm{N} 16^{\circ} 17^{\prime} 04^{\prime \prime} \mathrm{W}$ & $0-6$ & observation \\
\hline & & & $33^{\circ} 03^{\prime} 13.68^{\prime \prime} \mathrm{N} 16^{\circ} 17^{\prime} 03^{\prime \prime} \mathrm{W}$ & $0-6$ & observation \\
\hline & & $17-$ Oct-20 & $33^{\circ} 02^{\prime} 39.16^{\prime \prime} \mathrm{N} 16^{\circ} 17^{\prime} 36^{\prime \prime} \mathrm{W}$ & $0-6$ & observation \\
\hline & & 07-Dec-20 & $33^{\circ} 03^{\prime} 01.00^{\prime \prime} \mathrm{N} 16^{\circ} 19^{\prime} 38^{\prime \prime} \mathrm{W}$ & $0-6$ & observation \\
\hline & & 08-Dec-20 & $33^{\circ} 02^{\prime} 56.10^{\prime \prime} \mathrm{N} 16^{\circ} 18^{\prime} 36^{\prime \prime} \mathrm{W}$ & $0-6$ & observation \\
\hline \multirow{2}{*}{$\begin{array}{l}\text { Ocyropsis } \\
\text { crystallina }\end{array}$} & \multirow[t]{2}{*}{ Porto Santo } & $14-O c t-20$ & 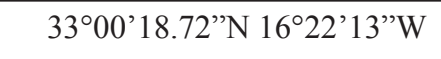 & $0-6$ & observation \\
\hline & & & $33^{\circ} 00^{\prime} 19.08^{\prime \prime} \mathrm{N} 16^{\circ} 22^{\prime} 13^{\prime \prime} \mathrm{W}$ & $0-6$ & Specimen studied \\
\hline Cestum veneris & Porto Santo & 10-Dec-20 & $33^{\circ} 03^{\prime} 05.60^{\prime \prime} \mathrm{N} 16^{\circ} 20^{\prime} 09^{\prime \prime} \mathrm{W}$ & 12 & Specimen studied \\
\hline $\begin{array}{l}\text { Beroe sp. } \\
\text { (cucumis?) }\end{array}$ & Madeira & 02-Mar-21 & $32^{\circ} 38^{\prime} 22.07^{\prime \prime} \mathrm{N} 16^{\circ} 49^{\prime} 50^{\prime \prime} \mathrm{W}$ & $0-5$ & Specimen studied \\
\hline
\end{tabular}


Identification of the specimens (observed and collected) was performed based on Mayer (1912), Mianzan (1999), Migotto \& Marques (2006), and Mills \& Haddock (2007). Unfortunately, we were not successful in preserving voucher specimens of the collected ctenophores.

Species occurrence data presented in Figure 5 was collected using the Global Biodiversity Information Facility database (GBIF 2021), the Ocean Biogeographic Information System (OBIS 2021) as well as published literature (see supplementary material).

\section{Results}

In total, four new and distinctive planktonic ctenophores were recorded for the first time in Madeira waters (Table 1, Fig. 1): three species were recorded in Porto Santo (Eurhamphaea vexilligera, Ocyropsis crystallina, and Cestum veneris) and one in Madeira Island (Beroe sp., cf cucumis). Eurhamphaea vexilligera was the most common with seven observations. Only two specimens of Ocyropsis crystallina, one of Cestum veneris and one of Beroe sp. were observed.
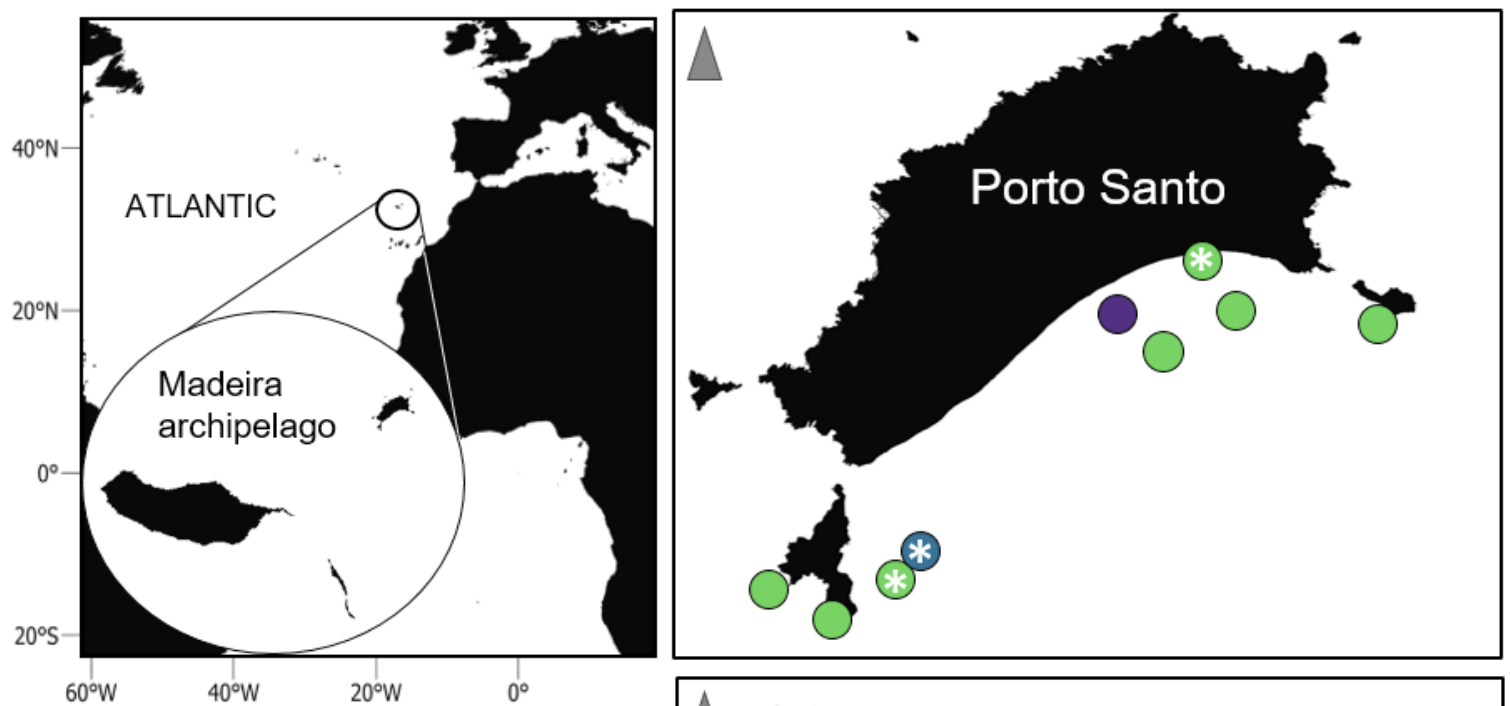

\section{Beroe sp.}

Eurhamphaea vexilligera

Ocyropsis crystallina

\section{Cestum veneris}

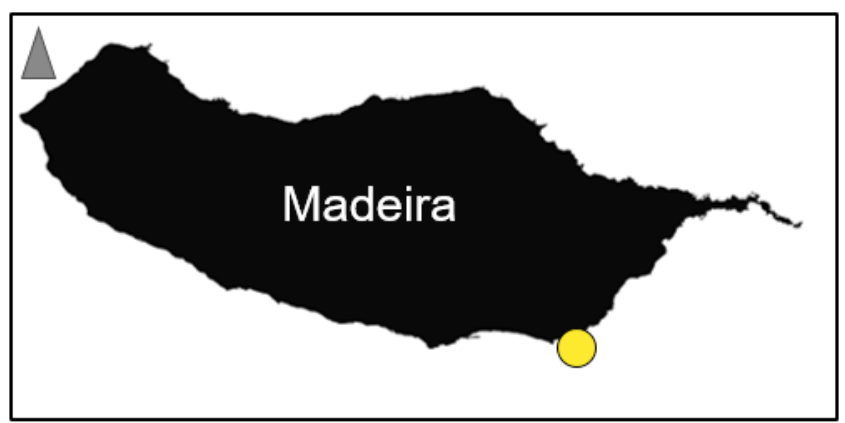

FIGURE 1. Madeira Archipelago including locations of ctenophore observations and collections (*)

\section{Systematic part}

\section{Class Tentaculata}

\section{Order Lobata}

Family Eurhamphaeidae

Eurhamphaea vexilligera Gegenbaur, 1856

(Table 1, Fig. 2) 
Synonym: Mnemia elegans M. Sars, 1856

Examined material: East coast of Ilhéu da Cal, Porto Santo Island, 3300'18'N 16 $22^{\prime} 13^{\prime \prime} \mathrm{W}$ and 3300'19'N $16^{\circ} 22^{\prime} 13.08^{\prime \prime} \mathrm{W}$. Several adults were observed during SCUBA diving, and two individuals were collected between 2 and 6 m depth. In Porto Santo harbour (33 $3^{\circ} 45^{\prime}$ N $\left.16^{\circ} 18^{\prime} 59^{\prime \prime} \mathrm{W}\right)$, one specimen was collected at the sea surface (0.5 m depth).

Description: Overall, body length of the sampled specimens varied from three to six $\mathrm{cm}$. The biggest specimen, around $10 \mathrm{~cm}$, was observed in situ (West coast of Ilhéu da Cal, 3300'13'N 16²3'34'W). The body was elongated, narrow with a noticeable compression in the tentacular axis (Fig. 2A). Two horn-shaped processes terminating in the long flexible filament are drawn out at the aboral apex (Fig. 2B). Subtentacular ctene rows extend onto these processes. Reddish-brown ink vesicles with bioluminescent properties follow the path of the substomodeal meridional canals (Fig. 2C).

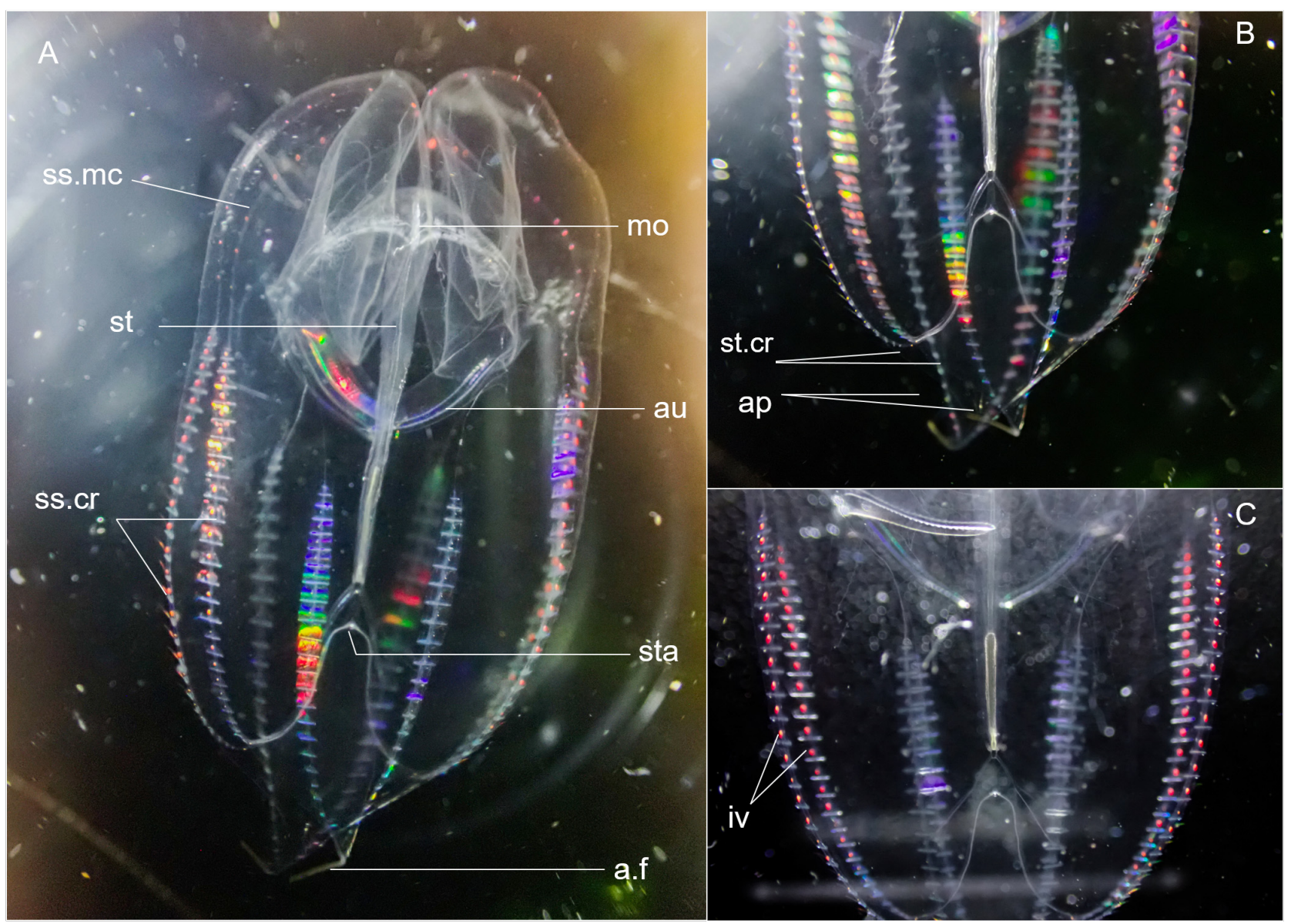

FIGURE 2. Eurhamphaea vexilligera Gegenbaur, 1856. A, total view of an adult in the stomodaeal plane; B, view of the aboral portion of the body in the stomodaeal plane; $\mathbf{C}$, view of a body section in the stomodaeal plane. Legends: a.f, aboral process/ filament; ap, apical horn-shape; au, auricle; i.v, ink vesicle; mo, mouth; ss.c, substomdaeal ctene row; ss.mc, substomodaeal meridional canal; sta, statocysts; st.cr, subtentacular ctene row; st, stomodaeum (pharynx). Photo credits: S.K.M Gueroun

\section{Family Ocyropsidae}

\section{Ocyropsis crystallina Rang, 1827}

(Table 1, Fig. 3)

Synonym: Ocyroe crystallina Rang, 1827

Examined material: East coast of Ilhéu da Cal, Porto Santo Island, 3300'19'N 16 22'13'W. Two individuals were observed during SCUBA diving; one specimen was collected between 2 and $6 \mathrm{~m}$ depth. 
Description: Body laterally compressed with two large flapping oral lobes. The auricles are flat and ribbonlike; their narrow edges are lined with long cilia. The stomodaeum is flat, with broadsides constricted near the middle (Fig. 3).

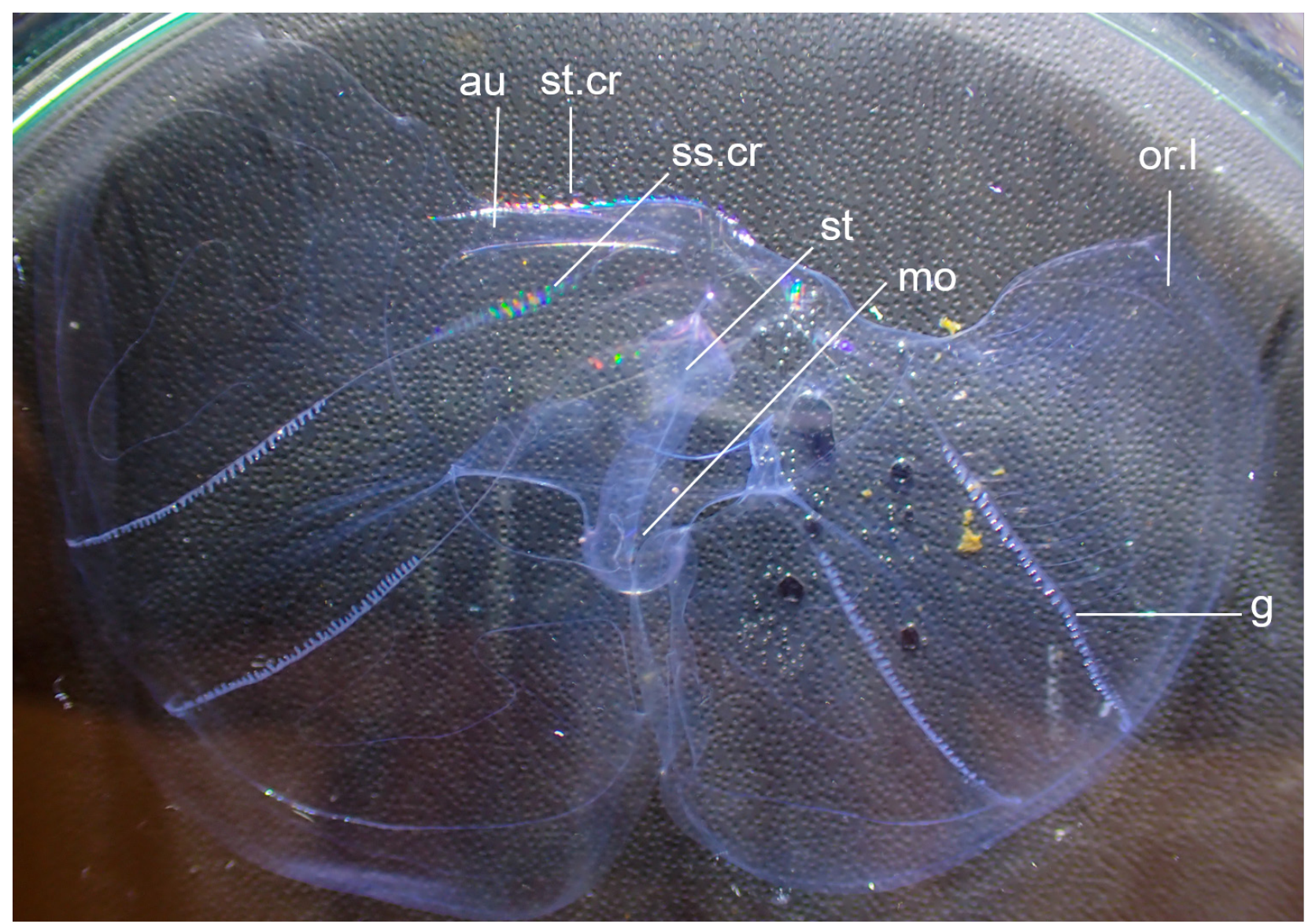

FIGURE 3. Ocyropsis crystallina Rang, 1827. Legends: $a u$, auricle; mo, mouth; $g$, gonads, or.l, oral lobe; ss.cr, substomdaeal ctene row; st.cr, subtentacular ctene row; sto, stomodaeal (pharynx). Photo credit: S.K.M. Gueroun

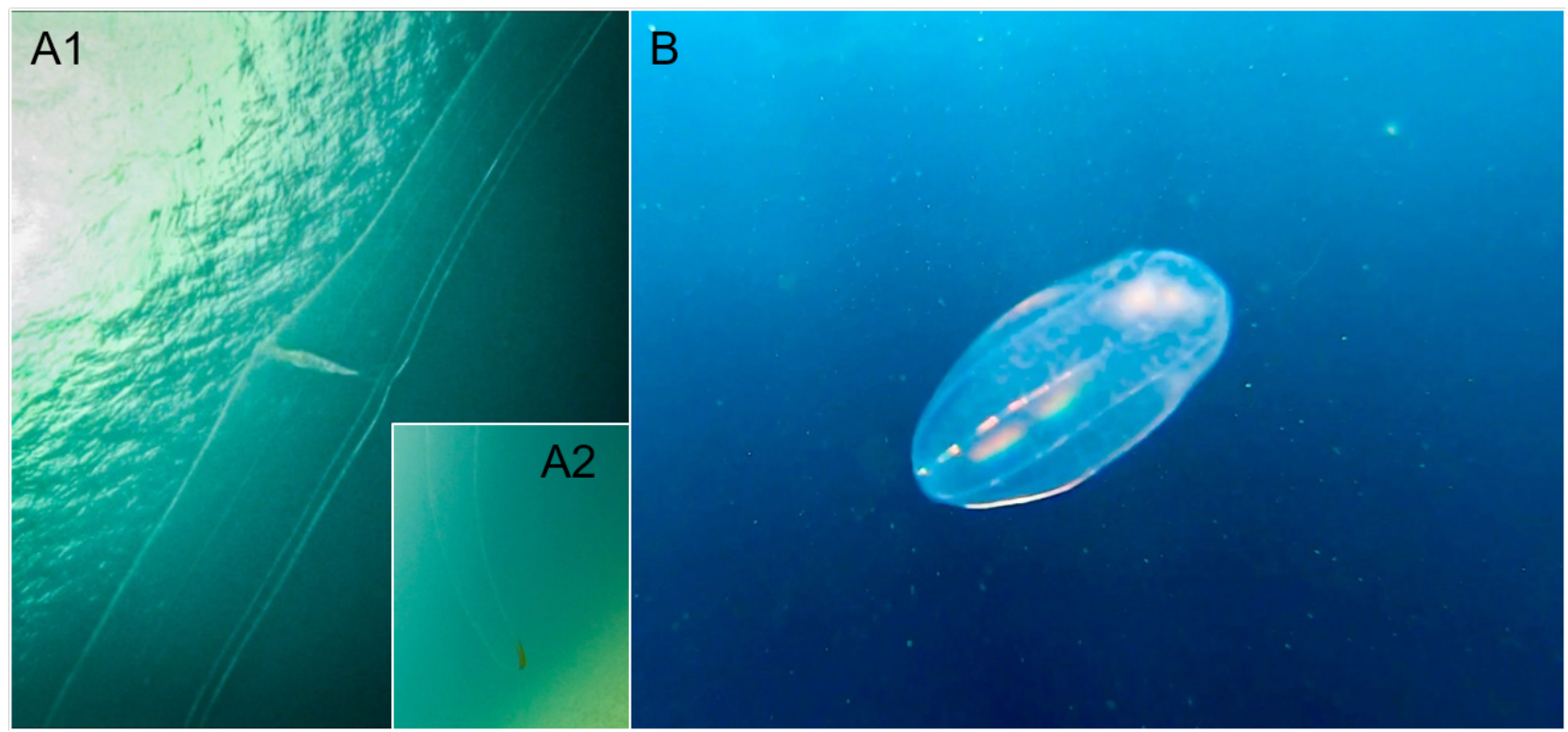

FIGURE 4. Photographies of (A1) Cestum veneris Lesueur, 1813 and (A2) the purplish-black pigment on its wingtips; (B) Beroe sp. Müller, 1776. Photo credit: C. veneris: F. Gizzi; Beroe sp.: M. Buzinkai 


\section{Order Cestida}

\section{Family Cestidae}

\section{Cestum veneris Lesueur, 1813}

(Table 1, Fig. 4A)

Synonymes: Cestus pectinalis Bigelow, 1904; Cestus veneris Chun, 1879

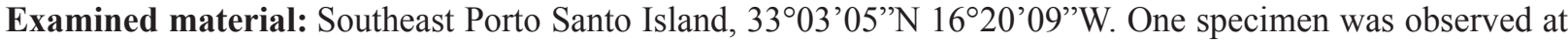
$12 \mathrm{~m}$ depth, near the sand floor, during a SCUBA dive.

Description: Body laterally expanded and flattened, long and ribbon-like, around $1 \mathrm{~m}$ in width, transparent. Presence of purplish-black pigment on its wingtips (brown-yellowish colour on the video record due to the light spectrum gradient) (Fig. 4A2).

Remark: While no individual was clearly photographed, some reports indicate $C$. veneris occurrence in the southern part of the Madeira Island (Peter Wirtz pers. comm).

\section{Class Nuda}

\section{Order Beroida}

\section{Family Beroidae}

\section{Genus Beroe sp. (cf cucumis) Müller, 1776}

(Table 1, Fig. 4B)

Examined material: South Madeira Island, $32^{\circ} 38^{\prime} 22^{\prime \prime} \mathrm{N} 16^{\circ} 49^{\prime} 50^{\prime \prime} \mathrm{W}$. One specimen was observed at around $2 \mathrm{~m}$ depth during a recreational free dive.

Description: Body cylindrical, flattened, opaque, without tentacles. Ctene rows with anastomosed canals.

Remark: The resolution of the photographed specimen is low due to the recording quality (GoPro Hero 7). Only two Beroe species have been recorded in Macaronesia: Beroe cucumis (Azores and Canary Islands) and Beroe ovata (Canary Islands) (Gueroun et al. 2021). As B. ovata aboral part tends to be wider than in B. cucumis, the specimen recorded in Madeira is more likely a $B$. cucumis.

\section{Discussion}

Ctenophores are fragile organisms that are not easily collected by nets, resulting in a general underestimation of their species richness, abundance, and ecological importance. During the last years, most ctenophore reports came from diving surveys and submersible records. Harbison (1985) suggested that ctenophores richness is mainly distributed in ocean deep-water, adding a layer of complexity/challenge for ctenophore diversity research.

Observations of O. crystallina, E. vexilligera, C. veneris, and Beroe sp. are not new in the Atlantic Ocean (Fig. 5). These ctenophores have mainly been recorded in the western Atlantic, with most of the observations ranging between 0 and $40^{\circ}$ latitudes. The nearest records have been: for E. vexilligera in the Canary Islands (Chun 1898), O. crystallina in the Canary Islands and Cape Verde (Moro et al. 2013; Christiansen et al. 2016), and C. veneris and Beroe spp. in three archipelagos (Azores, Canary Islands, and Cape Verde) (Chun 1898; Mayer 1912; Christiansen et al. 2016).

Although E. vexilligera, O. crystallina, and C. veneris are often considered epipelagic species (Harbison et al. 1978; Oliveira et al. 2016), specimens have been collected or observed in the mesopelagic zone (Harbison \& Miller 1986; Oliveira \& Migotto 2006; Lindsay et al. 2015; Hidaka et al. 2021). As carnivorous organisms, E. vexilligera preys on copepods, ostracods, siphonophores, and small pteropods. O. crystallina feeds on siphonophores, 
other ctenophores, large copepods, pteropods, amphipods, small fishes, and euphausiids. C. veneris preys on copepods, and Beroe spp. predate on other ctenophores and salps (Harbison et al. 1978).

Compared to other marine organisms, information on gelatinous zooplankton's functional roles in all marine ecosystems is still sparse. With such a lack of knowledge, more research is needed given the fact that (i) recent studies highlighted the importance of the so-called "jelly web" in planktonic oceanic food webs (Chi et al. 2020) and their role in pelagic-benthic coupling (Sweetman et al. 2014; Sweetman \& Chapman 2015); (ii) some ctenophores present a foreseeable invasive behaviour and proliferation potential; (iii) ctenophores can host different parasites (Martorelli 2001; San Martín et al. 2021) that might negatively affect other organisms and higher trophic levels. In this context, the present study takes place to increase our knowledge of gelatinous zooplankton in the Macaronesia region and particularly in the Madeira Archipelago (Gueroun et al. 2021).

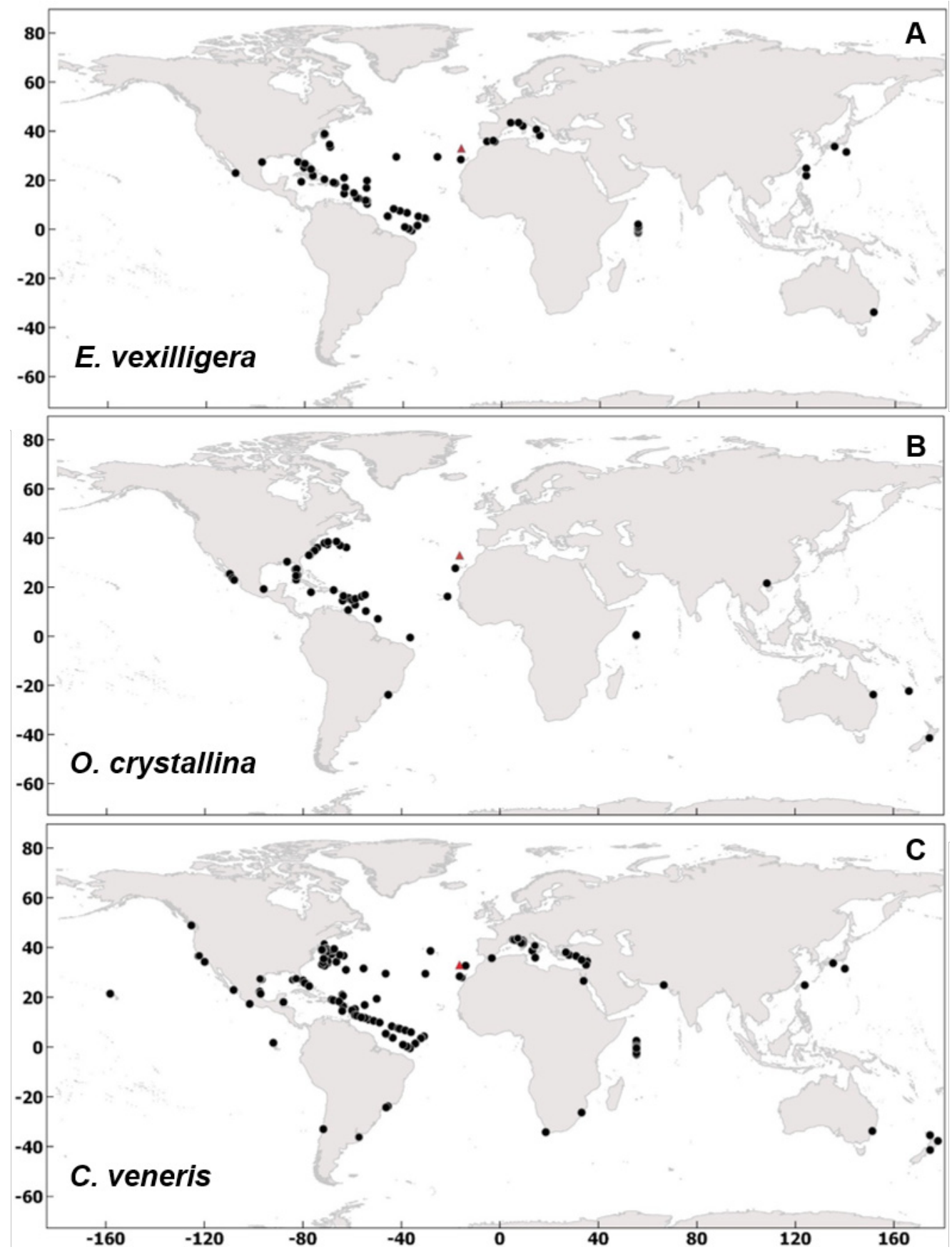

FIGURE 5. World distribution of (A) E.vexilligera, (B) O. crystallina, and (C) C. veneris. Red triangle: present records in Madeira Archipelago 


\section{Acknowledgements}

The authors would like to thank Matej Bukinkai for the video record of the Beroe sp., and Peter Wirtz for his personal communication. SKMG and SS are funded by the project GoJelly-A gelatinous solution to plastic pollution-funding from the European Union's Horizon 2020 research and innovation program (grant agreement No. 774499). FG is supported by a post-doctoral research fellowship granted by ARDITI in the framework of project RAGES [ARDITI-RAGES-2019-001]. SA is funded by MIMAR+ (MAC2/4.6d/249) and OCEANLIT projects (MAC2/4.6d/302) funded by the INTERREG MAC 2014-2020 program. JM is funded by the post-doctoral research fellowship [M1420-09-5369-FSE-000002]. JCC is funded by national funds through FCT - Fundação para a Ciência e a Tecnologia, I.P., under the Scientific Employment Stimulus - Institutional Call - (CEECINST/00098/2018). This study represents a contribution to the Expedition "MARE@Porto Santo 2020" organized by MARE-Madeira. Finally, this study also had the support of Fundaçabo para a Ciencia e Tecnologia (FCT) through the strategic project (UIDB/04292/2020) granted to MARE UI\&I.

\section{References}

Agassiz, A. (1865) North American Acalephæ. Illustrated Catalogue of the Museum of Comparative Zoölogy at Harvard College, 2, 1-234.

Alves, F., Canning-Clode, J., Ribeiro, C., Gestoso, I. \& Kaufmann, M. (2019) Local benthic assemblages in shallow rocky reefs find refuge in a marine protected area at Madeira Island. Journal of Coastal Conservation, 23, 373-383. https://doi.org/10.1007/s11852-018-0669-y

Bigelow, H.B. (1904) Medusae from the Maldive Islands. Bulletin of the Museum of Comparative Zoology at Harvard College, 39, 245-269.

Biscoito, M., Ribeiro, C. \& Freitas, M. (2018) Annotated checklist of the fishes of the archipelago of Madeira (NE Atlantic): I-Chondrichthyes. Zootaxa, 4429 (3), 459-494. https://doi.org/10.11646/zootaxa.4429.3.2

Boersma, M., Malzahn, A.M., Greve, W. \& Javidpour, J. (2007) The first occurrence of the ctenophore Mnemiopsis leidyi in the North Sea. Helgoland Marine Research, 61, 153-155. https://doi.org/10.1007/s10152-006-0055-2

Cacabelos, E., Gestoso, I., Ramalhosa, P., Riera, L., Neto, A.I. \& Canning-Clode, J. (2019) Intertidal assemblages across boulders and continous rocky shores: a multi-scale approach in a subtropical island. Marine Biodiversity, 49 (6), 2709-2723. https://doi.org/10.1007/s12526-019-01000-7

Chi, X., Dierking, J., Hoving, H., Lüskow, F., Denda, A., Christiansen, B., Sommer, U., Hansen, T. \& Javidpour, J. (2020) Tackling the jelly web: Trophic ecology of gelatinous zooplankton in oceanic food webs of the eastern tropical Atlantic assessed by stable isotope analysis. Limnology \& Oceanography, 66 (2), 289-305. https://doi.org/10.1002/lno.11605

Christiansen, B., Buchholz, C., Buchholz, F., Chi, X., Christiansen, S., Denda, A., Hauss, H., Hoving, H.J.T., Janßen, S., Kaufmann, M., Kronschnabel, A., Lüskow, F., Martin, B., Merten, V., Silva, P., Pinheiro, N., Springer, B., Zankl, S. \& Zeimet, T. (2016) SEAMOX: The influence of Seamounts and oxygen minimum zones on pelagic fauna in the Eastern Tropical Atlantic_Cruise No. MSM49-November 28-December 21, 2015-Las Palmas de Gran Canaria (Spain) Mindelo (Republic of Cape Verde). MARIA S. MERIAN-Berichte, MSM49, 1-42. https://doi.org/10.2312/cr_msm49

Chun, C. (1879) Die im Golf von Neapel erscheinenden Rippenquallen. Mittelmeer Zoologischen Station von Neapel zugleich repert Mittelmeerkd, 1, 180-217.

Chun, C. (1898) Die Ctenophoren der Plankton-Expedition. Ergebnisse der Plankton- Expedition der Humboldt-Stiftung, 2 , $1-32$.

Deidun, A. (2011) A collection of recent ctenophore sightings from the Maltese Islands. Journal of Black Sea/Mediterranean Environment, 17 (1), 4-13.

Diaz Briz, L., Sánchez, F., Marí, N., Mianzan, H. \& Genzano, G. (2017) Gelatinous zooplankton (ctenophores, salps and medusae): an important food resource of fishes in the temperate SW Atlantic Ocean. Marine Biology Research, 13 (6), 630-644. https://doi.org/10.1080/17451000.2016.1274403

Dinasquet, J., Titelman, J., Møller, L.F., Setälä, O., Granhag, L., Andersen, T., Bamstedt, U., Haraldsson, M., Hosia, A., Katajisto, T., Kragh, T., Kuparinen, J., Schrøter, M.L., Søndergaard, M., Tiselius, P. \& Riemann, L. (2012) Cascading effects of the ctenophore Mnemiopsis leidyi on the planktonic food web in a nutrient-limited estuarine system. Marine Ecology Progress Series, 460, 49-61. https://doi.org/10.3354/meps09770

Dutto, M.S., Genzano, G.N., Schiariti, A., Lecanda, J., Hoffmeyer, M.S. \& Pratolongo, P.D. (2017) Medusae and ctenophores 
from the Bahía Blanca Estuary and neighboring inner shelf (Southwest Atlantic Ocean, Argentina). Marine Biodiversity Records, 10, 14.

https://doi.org/10.1186/s41200-017-0114-1

Engell-Sørensen, K., Andersen, P. \& Holmstrup, M. (2009) Preservation of the invasive ctenophore Mnemiopsis leidyi using acidic Lugol's solution. Journal of Plankton Research, 31 (8), 917-920. https://doi.org/10.1093/plankt/fbp030

Freitas, R., Romeiras, M., Silva, L., Cordeiro, R., Madeira, P., González, J.A., Wirtz, P., Falcón, J.M., Brito, A., Floeter, S.R., Afonso, P., Proteiro, F., Viera-Rodriguez, M.A., Neto, A.I., Haroun, R., Farminhao, J.N., Rebelo, A.C., Baptista, L., Melo, C.S., Martinez, A., Nunez, J., Berning, B., Johnson, M.E. \& Avila, S.P. (2019) Restructuring of the "Macaronesia" biogeographic unit: A marine multi- taxon biogeographical approach. Scientific Reports, 9, 15792. https://doi.org/10.1038/s41598-019-51786-6

Gegenbaur, C. (1856) Studien über Organisation und Systematik der Ctenophoren. Archiv für Naturgeschichte, XXII, 163-205

Gibbons, M.J., Haddock, S.H.D., Matsumoto, G.I. \& Foster, C. (2021) Records of ctenophores from South Africa. PeerJ, 9 , e10697. https://doi.org/10.7717/peerj.10697

Giribet, G. \& Edgecombe, G. (2020) The invertebrate tree of life. Princeton University Press, Princeton, New Jersey, 589 pp. https://doi.org/10.1515/9780691197067

Greve, W. (1975) Ctenophora. Fiche d'Identification du Zooplankton, 146, 6-11.

Gueroun, S.K.M., Javidpour, J., Andrade, C., Nogueira, N., Freitas, M. \& Canning-Clode, J. (2021) Pelagic Cnidaria and Ctenophora diversity patterns and trends in Macaronesia insular systems (NE Atlantic). Marine Biodiversity, 51, 32. https://doi.org/10.1007/s12526-021-01174-z

Haddock, S.H.D. (2007) Comparative feeding behavior of planktonic ctenophores. Integrative and Comparative Biology, 47 (6), 847-853. https://doi.org/10.1093/icb/icm088

Hansson, H.G. (2006) Ctenophores of the Baltic and adjacent Seas - the invader Mnemiopsis is here! Aquatic Invasions, 1 (4), 295-298. https://doi.org/10.3391/ai.2006.1.4.16

Harbison, G.R. (1985) Toward a study of the biogeography of pelagic ctenophores. Proceedings of an international conference, Netherlands, 1985, 112-117.

Harbison, G.R., Madin, L.P. \& Swanberg, N.R. (1978) On the natural history and distribution of oceanic ctenophores. Deep-Sea Research, 25 (3), 237-256. https://doi.org/10.1016/0146-6291(78)90590-8

Harbison, G.R. \& Miller, R.L. (1986) Not all ctenophores are hermaphrodites. Studies on the systematics, distribution, sexuality and development of two species of Ocyropsis. Marine Biology, 90, 413-424. https://doi.org/10.1007/BF00428565

Hidaka, M., Nishikawa, J. \& Lindsay, D.J. (2021) Gelatinous zooplankton community around a hydrothermally active deep-sea caldera: Results from ROV video records. Plankton and Benthos Research, 16 (1), 40-58. https://doi.org/10.3800/pbr.16.40

Kaufmann, M.J., Santos, F. \& Maranhao, M. (2015) Checklist of nano- and microphytoplankton off Madeira Island (Northeast Atlantic) with some historical notes. Nova Hedwigia, 101, 205-232. https://doi.org/10.1127/nova_hedwigia/2015/0265

Knowler, D. (2005) Reassessing the costs of biological invasion: Mnemiopsis leidyi in the Black sea. Ecological Economics, $52,187-199$. https://doi.org/10.1016/j.ecolecon.2004.06.013

Lesueur, C.A. (1813) Mémoire sur quelques nouvelles espèces d'animaux mollusques et radiaires recueillis dans la Méditerranée près de Nice. Nouveau Bulletin des Sciences par la Société Philomatique de Paris, Series 2, 3 (69), 281-285

Licandro, P., Blackett, M., Fischer, A., Hosia, A., Kennedy, J., Kirby, R.R., Raab, K., Stern, R. \& Tranter, P. (2015) Biogeography of jellyfish in the North Atlantic, by traditional and genomic methods. Earth System Science Data, 7, $173-191$. https://doi.org/10.5194/essd-7-173-2015

Lindsay, D.J., Umetsu, M., Grossmann, M., Miyake, H. \& Yamamoto, H. (2015) The gelatinous macroplankton community at the Hatoma Knoll hydrothermal vent. In: Ishibashi, J., Okino, K. \& Sunamura, M. (Eds.), Subseafloor Biosphere Linked to Hydrothermal Systems: TAIGA Concept. Springer, Tokyo, pp. 639-666. https://doi.org/10.1007/978-4-431-54865-2_51

Longhurst, A., Sathyendranath, S., Platt, T. \& Caverhill, C. (1995) An estimate of global primary production in the ocean from satellite radiometer data. Journal of Plankton Research, 17, 1245-1271. https://doi.org/10.1093/plankt/17.6.1245

Martorelli, S.R. (2001) Digenea parasites of jellyfish and ctenophores of the southern Atlantic. Hydrobiologia, 451, 305-310. https://doi.org/10.1023/A:1011862406670

Mayer, A.G. (1912) Ctenophores of the Atlantic coast of North America. Carnegie Institution, Washington, 58 pp. https://doi.org/10.5962/bhl.title.5968

Mianzan, H.W. (1999) Ctenophora. In: Demetrio, B. (Ed.), South Atlantic zooplankton. Vol1. Backhuys Publishers, Leiden pp. 
$561-573$.

Migotto, A.E. \& Marques, A.C. (2007) Identification key for the ctenophores from Brazilian coast. Biota Neotropica, 7 (3), $242-350$.

Mills, C.E. \& Haddock, S.H.D. (2007) Key to the Ctenophora. In: Carlton, J.T. (Ed.), The Light and Smith Manual Intertidal Invertebrates from Central California to Oregon, Completely Revised and Expanded. University of California Press, Oakland, California, pp 189-199. https://doi.org/10.1525/9780520930438-015

Moro, L., Boelkhe, V., Escatllar, J. \& Bacallado, J.J. (2013) Nota sobre la presencia de Ocyropsis crystallina (Rang, 1828) (Ctenophora: Lobata) en las islas Canarias. Revista de la Academia Canaria de Ciencias, 25, 129-133.

Müller, O.F. (1776) Zoologice Danicce Prodromus, seu Animalium Danice et Norvegice indigenarum characteres, nomina, et synonyma imprimis popularium. typis Hallageriis, Havniæ [Copenhagen], xxxii +274 pp. https://doi.org/10.5962/bhl.title.63795

Narciso, Á., Caldeira, R., Reis, J., Hoppenrath, M., Cachão, M. \& Kaufmann, M. (2019) The effect of a transient frontal zone on the spatial distribution of extant coccolithophores around the Madeira archipelago (Northeast Atlantic). Estuarine, Coastal and Shelf Science, 223, 25-38. https://doi.org/10.1016/j.ecss.2019.04.014

Ohtsuka, S., Koike, K., Lindsay, D., Nishikawa, J., Miyake, H., Kawahara, M., Mulyadi, Mujiono, N., Hiromi, J. \& Komatsu, H. (2009) Symbionts of marine medusae and ctenophores. Plankton and Benthos Research, 4, 1-13. https://doi.org/10.3800/pbr.4.1

Oliveira, O.M.P. \& Migotto, A.E. (2006) Pelagic ctenophores from the São Sebastião Channel, southeastern Brazil. Zootaxa, $1183(1), 1-26$. https://doi.org/10.11646/zootaxa.1183.1.1

Oliveira, O.M.P., Miranda, T.P., Araujo, E.M., Ayón, P., Cedeño-Posso, C.M., Cepeda-Mercado, A.A., Córdova, P., Cunha, A.F., Genzano, G.N., Haddad, M.A., Mianzan, H.W., Migotto, A.E., Miranda, L.S., Morandini, A.C., Nagata, R.M., Nascimento, K.B., Nogueira, M., Palma, S., Quiñones, J., Rodriguez, C.S., Scarabino, F., Schiariti, A., Stampar, S.N., Tronolone, V.B. \& Marques, A.C. (2016) Census of Cnidaria (Medusozoa) and Ctenophora from South American marine waters. Zootaxa, 4194 (1), 1-256. https://doi.org/10.11646/zootaxa.4194.1.1

Purcell, J.E. (2005) Climate effects on formation of jellyfish and ctenophore blooms: a review. Journal of the Marine Biological Association of the UK, 85, 461-476. https://doi.org/10.1017/S0025315405011409

Ramalhosa, P., Gestoso, I., Rocha, R.M., Lambert, G. \& Canning-clode, J. (2021) Ascidian biodiversity in the shallow waters of the Madeira Archipelago: Fouling studies on artificial substrates and new records. Regional Studies in Marine Science, 43, 101672. https://doi.org/10.1016/j.rsma.2021.101672

Rang, S. (1827) Description d'un genre nouveau de la classe des Acalèphes. Bulletin d'histoire naturelle de la Socieitei Linneienne de Bordeaux, 1 (4), 316-319

Rankin, J.J. (1956) The structure and biology of Vallicula multiformis, gen. et sp. nov., a platyctenid ctenophore. Journal of the Linnean Society of London, Zoology, 43 (289), 55-71. https://doi.org/10.1111/j.1096-3642.1956.tb02507.x

Ribeiro, C., Araújo, A.J., Biscoito, M. \& Freitas, M. (2005) Fish assemblages of Cais do Carvão Bay (Madeira Island) determined by the visual census technique. Journal of Fish Biology, 67, 1568-1584. https://doi.org/10.1111/j.1095-8649.2005.00861.x

Sala, I., Caldeira, R.M., Estrada-allis, S.N., Froufe, E. \& Couvelard, X. (2013) Lagrangian transport pathways in the northeast Atlantic and their environmental impact. Limnology and Oceanography: Fluids and Environments, 3, 40-60. https://doi.org/10.1215/21573689-2152611

San Martín, G., Álvarez-Campos, P., Kondo, Y., Núñez, J., Fernández-Álamo, M.A., Pleijel, F., Goetz, F.E., Nygren, A. \& Osborn, K. (2021) New symbiotic association in marine annelids: ectoparasites of comb jellies. Zoological Journal of the Linnean Society, 191, 672-694. https://doi.org/10.1093/zoolinnean/zlaa034

Sars, M. (1856) Fauna littoralis Norvegiae, oder Beschreibung und Abbildungen neuer oder wenig bekannten Seethiere. Frederik D. Beyer, Bergen, 144 pp

Sullivan, B.K., Keuren, D. Van \& Clancy, M. (2001) Timing and size of blooms of the ctenophore Mnemiopsis leidyi in relation to temperature in Narragansett Bay, RI. In: Purcell J.E., Graham, W.M. \& Dumont, H.J. (Eds.), Jellyfish Blooms: Ecological and Societal Importance. Springer, Dordrecht, pp. 113-120. https://doi.org/10.1023/A:1011848327684

Sweetman, A.K. \& Chapman, A. (2015) First assessment of flux rates of jellyfish carcasses (jelly-falls) to the benthos reveals the importance of gelatinous material for biological C-cycling in jellyfish-dominated ecosystems. Frontiers in Marine Science, 2, 47. https://doi.org/10.3389/fmars.2015.00047

Sweetman, A.K., Smith, C.R., Dale, T. \& Jones, D.O.B. (2014) Rapid scavenging of jellyfish carcasses reveals the importance 
of gelatinous material to deep-sea food webs. Proceedings of the Royal Society B, 281 (1796), 20142210. https://doi.org/10.1098/rspb.2014.2210

Thibault-botha, D. \& Bowen, T. (2004) Impact of formalin preservation on Pleurobrachia bachei (Ctenophora). Journal of experimental Marine Biology and Ecology, 303, 11-17. https://doi.org/10.1016/j.jembe.2003.10.017

Wirtz, P. (1998) Twelve invertebrate and eight fish species new to the marine fauna of Madeira, and a discussion of the zoogeography of the area. Helgolander Meeresuntersuchungen, 52, 197-207. https://doi.org/10.1007/BF02908748

Wirtz, P. (2007) On a collection of hydroids (Cnidaria, Hydrozoa) from the Madeira archipelago. Arquipélago-Life and Marine Sciences, 24, 11-16.

Wirtz, P., Fircke, R. \& Biscoito, J. (2008) The coastal fishes of Madeira Island-new records and an annotated checklist. Zootaxa, $1715(1), 1-26$.

https://doi.org/10.11646/zootaxa.1715.1.1 